Potapenko S. V. Determination of significant prognostic factors in the development of magnesium deficiency in children and adolescents with gastroesophageal reflux disease. Journal of Education, Health and Sport. 2020;10(12):125-137. eISSN 2391-8306. DOI http://dx.doi.org/10.12775/JEHS.2020.10.12.012

https://apcz.umk.pl/czasopisma/index.php/JEHS/article/view/JEHS.2020.10.12.012

https://zenodo.org/record/4321363

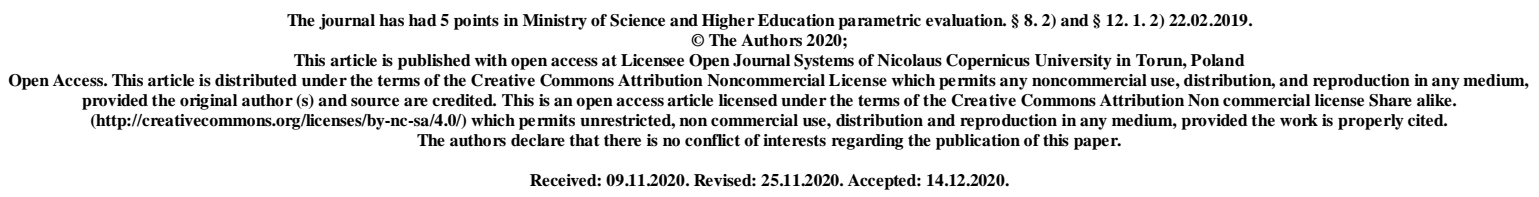

UDK 616.333-008.6-053.2-07-06

\title{
DETERMINATION OF SIGNIFICANT PROGNOSTIC FACTORS IN THE DEVELOPMENT OF MAGNESIUM DEFICIENCY IN CHILDREN AND ADOLESCENTS WITH GASTROESOPHAGEAL REFLUX DISEASE
}

\author{
S. V. Potapenko
}

\section{Zaporizhzhia State Medical University, Zaporizhzhia, Ukraine}

Potapenko S. V., MD, Assistant of the Department of Children Diseases, Zaporizhzhia State Medical University, Ukraine; 28A, Novgorodskaia street, Zaporizhzhia, 69076;

Tel .: +380673552554, e-mail: sergeypot@ gmail.com; ID orcid 0000-0002-2511-9257

\section{Abstract}

The aim of the work is to determine the factors of the course of GERD in children and adolescents which are important for predicting the development of magnesium deficiency.

Materials and methods of research. For the study 77 people aged 9 to 14 years, who have gastroesophageal reflux disease with endoscopically positive diagnostic result, were examined. All children who were involved in the study underwent laboratory tests of serum magnesium, intracellular (erythrocyte) magnesium, and calcium levels. The ratio of calcium and intracellular magnesium was also considered as an indicator of latent magnesium deficiency. Magnesium level in patients with GERD were compared with control group, which consisted of 20 children without GERD. The odds ratio and confidence intervals for a large number of anamnestic, clinical and instrumental factors of GERD were calculated to 
determine significant prognostic factors for the development of magnesium deficiency, after which the indicators of the relative risk and the minimum and maximum predictive coefficients for these factors were determined. Based on the indicators of the minimum and maximum prognostic coefficient, a range of the probability of magnesium deficiency in patients with GERD was formed.

Results. Based on the determination of the level of serum, erythrocyte magnesium,

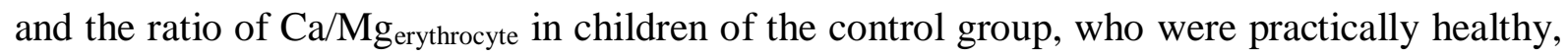
the standard deviation $(\delta)$ was calculated, and the corridors of laboratory parameters corresponding to the normal level of magnesium, indicators of latent deficiency (from $\delta$ to $2 \delta$ ) and indicators of deficiency of magnesium (more than $2 \delta$ ) were determined. In the group with GERD normal magnesium levels were discovered in $41.6 \%$ of children. A total of $19.5 \%$ of patients had latent magnesium deficiency and 39\% of children had magnesium deficiency. For the analysis were selected: hyperacidity ( $\mathrm{pH}$ 0.86-1.59), which had an odds ratio of 3.47; the reflux esophagitis 2-3 stages with an odds ratio of 68.64; an increase in LF and HF values day and night, an increase in the daytime $\mathrm{LF} / \mathrm{HF}$ ratio, an increase in the stress index, an increase in PAPR and average circadian index values. Based on the indicators of the minimum and maximum prognostic coefficient, a range of the probability of magnesium deficiency in patients with GERD was formed. With the sum of the predictive coefficients of each significant factor from 13.3 to 31.0 , the probability of magnesium deficiency is low; the range from 31.1 to 48.8 corresponds to the average probability, and the range of 48.9 to 66.5 indicates a significant possibility of a magnesium deficiency in a patient with GERD.

Conclusion. It was determined that the factors of hyperacidity and the reflux esophagitis, some indicators of heart rate variability (LF and HF day and night, an increase in the daytime LF/HF ratio, an increase in the stress index, an increase in PAPR and average indicators of the circadian index) can be used to predict the development of magnesium deficiency in children with GERD. The practical application of the predictive coefficients of the given factors will make it possible to timely correct magnesium deficiency and will positively affect the quality of GERD treatment in children and adolescents.

Key words: prognosis; magnesium deficiency; children; adolescents; GERD. 


\title{
ВИЗНАЧЕННЯ ПРОГНОСТИЧНО ЗНАЧУЩІХ ФАКТОРІВ РОЗВИТКУ МАГНІСВОГО ДЕФІЦИТУ У ДІТЕЙ ТА ПІДЛІТКІВ 3 ГАСТРОЕЗОФАГЕАЛЬНОЮ РЕФЛЮКСНОЮ ХВОРОБОЮ
}

\author{
С.В. Потапенко
}

\section{Запорізький державний медичний університет, Запоріжжя, Україна}

\section{Резюме}

Мета роботи. Визначити фактори перебігу ГЕРХ у дітей та підлітків, що мають значення для прогнозування розвитку дефіциту магнію.

Матеріали та методи дослідження. Було обстежено 77 осіб віком від 9 до 17 років у яких було діагностовано ендоскопічно-позитивну гастроезофагеальну рефлюксну хворобу. Всім дітям, що брали участь у дослідженні проводилось лабораторне визначення сироваткового магнію, внутришньоклітинного (еритроцитарного) магнію та рівня кальцію. Також було враховано співвідношення кальцію та внутрішньоклітинного магнію, як показника латентного дефіциту магнію. Показники магнію у пацієнтів з ГЕРХ порівнювались 3 аналогічними показниками групи контролю, що складалася 320 дітей без ГЕРХ. Для визначення прогностично значущих факторів розвитку дефіциту магнію було розраховано відношення шансів та довірені інтервали для великої кількості анамнестичних, клінічних та інструментальних факторів ГЕРХ, після чого було визначено показники відносного ризику та мінімальний і максимальний прогностичні коефіцієнти для цих факторів. На підставі показників мінімального та максимального прогностичного коефіцієнту було сформовано діапазон вірогідності наявності дефіциту магнію у пацієнтів з ГЕРХ.

Результати. На підставі визначення у дітей групи контролю, що були практично здоровими, рівня сироваткого, еритроцитарного магнію, а також співвідношення $\mathrm{Ca} / \mathrm{Mg}_{\text {еритр, }}$ розраховано стандартне відхилення $(\delta)$, та визначені коридори лабораторних показників, що відповідали нормальному рівню магнію, показникам латентного дефіциту (від $\delta$ до $2 \delta$ ) та показникам дефіциту магнію (більше $2 \delta$ ). В групі 3 ГЕРХ виявлено 41,6\% дітей 3 нормальним рівнем магнію. Пацієнти 3 латентним дефіцитом магнію склали 19,5\%, діти з дефіцитом магнію зустрічалися у 39\%. Для аналізу нами було відібрано: гіперацидність (рН 0,86-1,59), що мала показник відношення шансів 3,47; наявність рефлюкс-езофагіту 2-3 ст. 3 відношенням шансів 
68,64; підвищення показників LF та HF вдень та вночі, підвищення денного співвідношення LF/HF, підвищення показника стрес-індексу, підвищення PAPR та середні показники циркадного індексу. На підставі показників мінімального та максимального прогностичного коефіцієнту було сформовано діапазон вірогідності наявності дефіциту магнію у пацієнтів з ГЕРХ. При сумі прогностичних коефіцієнтів кожного значущого фактору від 13,3 до 31,0 вірогідність наявності дефіциту магнію слабка; діапазон від 31,1 до 48,8 відповідає середній вірогідності, а потрапляння в діапазон 48,9-66,5 свідчить про значну вірогідність наявності у пацієнта з ГЕРХ дефіциту магнію.

Висновок. Визначено, що фактори гіперацидності та наявність рефлюксезофагіту, деякі показники варіабельності серцевого ритму (LF та HF вдень та вночі, підвищення денного співвідношення LF/HF, підвищення показника стрес-індексу, підвищення PAPR та середні показники циркадного індексу) можуть бути використані для прогнозування розвитку дефіциту магнію у дітей з ГЕРХ. Практичне застосування прогностичних коефіцієнтів наведених факторів дозволить своєчасно корегувати дефіцит магнію, що позитивно відобразиться на якості лікування ГЕРХ у дітей та підлітків.

Ключові слова: прогноз; дефіцит магнію; діти; підлітки; ГЕРХ.

\section{ОПРЕДЕЛЕНИЕ ПРОГНОСТИЧЕСКИХ ЗНАЧИМЫХ ФАКТОРОВ РАЗВИТИЯ МАГНИЕВОГО ДЕФИЦИТА У ДЕТЕЙ И ПОДРОСТКОВ С ГАСТРОЭЗОФАГЕАЛЬНОЙ РЕФЛЮКСНОЙ БОЛЕЗНЬЮ}

\section{С. В. Потапенко}

Запорожский государственный медицинский университет, Запорожье, Украина

\section{Резюме}

Цель работы. Определить факторы течения ГЭРБ у детей и подростков, имеющих значение для прогнозирования развития дефицита магния.

Материалы и методы. Было обследовано 77 человек в возрасте от 9 до 17 лет, у которых было диагностирована эндоскопически-положительная гастроэзофагеальная рефлюксная болезнь. Всем детям, которые принимали участие в исследовании, проводилось лабораторное определение сывороточного магния, внутриклеточного 
(эритроцитарного) магния и уровня кальция. Также было учтено соотношение кальция и внутриклеточного магния, как показателя латентного дефицита магния. Показатели магния у пациентов с ГЭРБ сравнивались с аналогичными показателями группы контроля, которая состояла из 20 детей без ГЭРБ. Для определения прогностически значимых факторов развития дефицита магния было рассчитано отношение шансов и доверенные интервалы для большого количества анамнестических, клинических и инструментальных факторов ГЭРБ, после чего были определены показатели относительного риска и минимальный и максимальный прогностические коэффициенты для этих факторов. На основании показателей минимального и максимального прогностического коэффициента был сформирован диапазон вероятности наличия дефицита магния у пациентов с ГЭРБ.

Результаты. На основании определения у детей группы контроля, которые были практически здоровыми, уровня сыворотки, эритроцитарного магния, а также

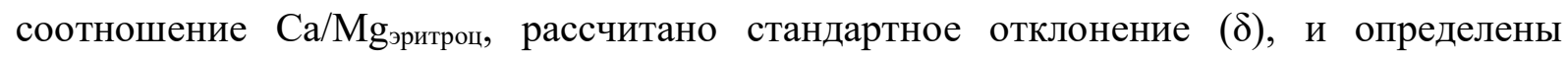
коридоры лабораторных показателей, соответствующих нормальному уровню магния, показателям латентного дефицита (от $\delta$ до $2 \delta$ ) и показателям дефицита магния (более $2 \delta$ ). В группе с ГЭРБ выявлено 41,6\% детей с нормальным уровнем магния. Пациенты с латентным дефицитом магния составили 19,5\%, дети с дефицитом магния встречались в 39\% случаев. Для анализа нами были отобраны: гиперацидность (pH 0,86-1,59), имевшая показатель отношения шансов 3,47; наличие рефлюкс-эзофагита 2-3 ст. с отношением шансов 68,64; повышение показателей LF и HF днем и ночью, повышение дневного соотношения LF/HF, повышение показателя стресс-индекса, повышение PAPR и средние показатели циркадного индекса. На основании показателей минимального и максимального прогностического коэффициента был сформирован диапазон вероятности наличия дефицита магния у пациентов с ГЭРБ. При сумме прогностических коэффициентов каждого значимого фактора от 13,3 до 31,0 вероятность наличия дефицита магния слабая; диапазон от 31,1 до 48,8 соответствует средней вероятности, а попадание в диапазон 48,9-66,5 свидетельствует о значительной вероятность наличия у пациента с ГЭРБ дефицита магния.

Вывод. Определено, что факторы гиперацидности и наличие рефлюксэзофагита, некоторые показатели вариабельности сердечного ритма (LF и HF днем и ночью, повышение дневного соотношения LF/HF, повышение показателя стрессиндекса, повышение PAPR и средние показатели циркадного индекса) могут быть использованы для прогнозирования развития дефицита магния у детей с ГЭРБ. 
Практическое применение прогностических коэффициентов приведенных факторов позволит своевременно корректировать дефицит магния, что положительно отразится на качестве лечения ГЭРБ у детей и подростков.

\section{Ключевые слова: прогноз; дефицит магния; дети; подростки; ГЭРБ.}

Introduction. Magnesium deficiency is a syndrome caused by a decrease of the magnesium level in various organs and systems, which has many symptoms that indicate a multi-organ functional disorder.

Symptoms of magnesium deficiency can be general: tiredness, chronic fatigue, irritability, anxiety, sleep disorder, attention and memory impairment. By the cardiovascular system: heartache, tachyarrhythmias, blood pressure lability; by the nervous system: tics, skin sensitivity disorders; by the respiratory system: bronchial spasms; by digestive system: nausea, abdominal pain, dyspepsia.

The development of magnesium deficiency in the body is due to social conditions and lifestyle, environmental conditions and dietary habits, various stressful situations and diseases.

The degree of absorption disorders depends on the rate and reversibility of the damage during the digestive tract. The development of the pathology of the gastrointestinal tract in its pathogenesis goes the way from minimal, reverse, functional disorders to organic pathological changes. According to specialized literature, the autonomic imbalance of the body is an important pathogenetic component in the development of many functional and organic disorders of the digestive system. Thus, the identification of magnesium deficiency and its effect on the development of autonomic dysfunction can help in the early correction of these disorders and reduce the frequency of chronic diseases of the gastrointestinal tract in children.

Considering the large biological role of magnesium and its participation in many biochemical processes of the body, timely detection and correction of magnesium deficiency allows preventing the development of severe course and complications of existing pathological conditions, including GERD.

Materials and methods. For the study 77 people aged 9 to 14 years, who has gastroesophageal reflux disease with endoscopically positive diagnostic result, were examined. All children who were involved in the study underwent laboratory tests of serum magnesium, intracellular (erythrocyte) magnesium, and calcium levels. The ratio of calcium and intracellular magnesium was also considered as an indicator of latent magnesium deficiency. Magnesium levels in patients with GERD were compared with control group, 
which consisted of 20 children without GERD. The odds ratio and confidence intervals for a large number of anamnestic, clinical and instrumental factors of GERD were calculated to determine significant prognostic factors for the development of magnesium deficiency, after which the indicators of the relative risk and the minimum and maximum predictive coefficients for these factors were determined. Based on the indicators of the minimum and maximum prognostic coefficient, a range of the probability of magnesium deficiency in patients with GERD was formed.

The aim of the work. To identify the factors of GERD in children and adolescents that are important for predicting the development of magnesium deficiency.

Results. Levels of serum, erythrocyte magnesium and $\mathrm{Ca} / \mathrm{Mg}_{\text {erythrocyte }}$ ratio in children who were in good health $(\mathrm{n}=20)$ were used to calculate the standard deviation $(\delta)$, and to determine the corridors of laboratory parameters (Table 1), which corresponded to normal magnesium levels, indicators of latent deficiency (from $\delta$ to $2 \delta$ ) and indicators of magnesium deficiency (more than $2 \delta$ ). The erythrocyte magnesium index in the control group was $2.11 \pm$ $0.4 \mathrm{mmol} / \mathrm{l}$, and the $\mathrm{Ca} / \mathrm{M}$ ratio was. $1.18 \pm 0.18$.

Table 1 - Corridors of determining the level of erythrocyte magnesium and the ratio of $\mathrm{Ca} / \mathrm{Mg}_{\text {erythrocyte }}$

\begin{tabular}{|c|c|c|c|}
\hline & Norm & $\begin{array}{c}\text { Latent magnesium } \\
\text { deficiency }\end{array}$ & $\begin{array}{c}\text { Magnesium } \\
\text { deficiency }\end{array}$ \\
\hline $\begin{array}{c}\text { Erythrocyte } \mathrm{Mg} \\
(\mathrm{mmol} / \mathrm{l})\end{array}$ & $1.71-2.51$ & $1.31-1.7$ & 1.3 and less \\
\hline $\begin{array}{c}\mathrm{Ca} / \mathrm{Mg} \text { erythrocyte ratio } \\
\text { (conv. unit) }\end{array}$ & $1-1.36$ & $1.37-1.54$ & 1.55 and more \\
\hline
\end{tabular}

Based on these data in children with GERD, the level of magnesium in the body was analyzed.

$51 \%$ of children with normal magnesium levels, $22 \%$ of children with latent deficiency and $27 \%$ of children with magnesium deficiency were found (Fig. 1).

After analyzing children with GERD in the ratio of $\mathrm{Ca} / \mathrm{Mg}_{\text {erythrocyte }}$ (Fig. 2), the following data were obtained.

The number of patients with a normal magnesium level is $42 \%$ (as opposed to $51 \%$ compared with erythrocyte magnesium level), $19 \%$ with $\mathrm{Ca} / \mathrm{Mg}_{\text {erythrocyte }}$ ratio, which correspond to latent magnesium deficiency (as opposed to 22\%), and 39\% children with magnesium deficiency ( $27 \%$ compared with erythrocyte magnesium). 


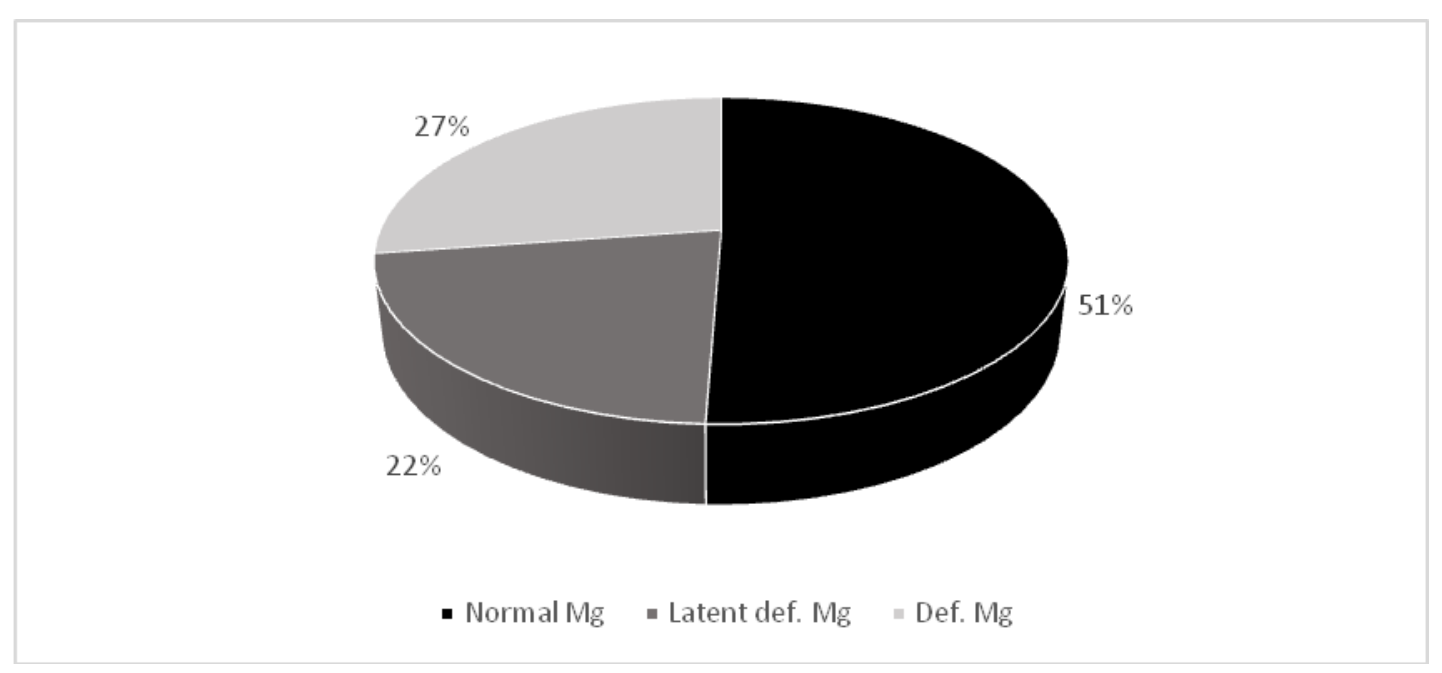

Fig. 1 - The ratio of the number of children in the main group with normal levels, latent deficiency and magnesium deficiency in parameters of erythrocyte magnesium

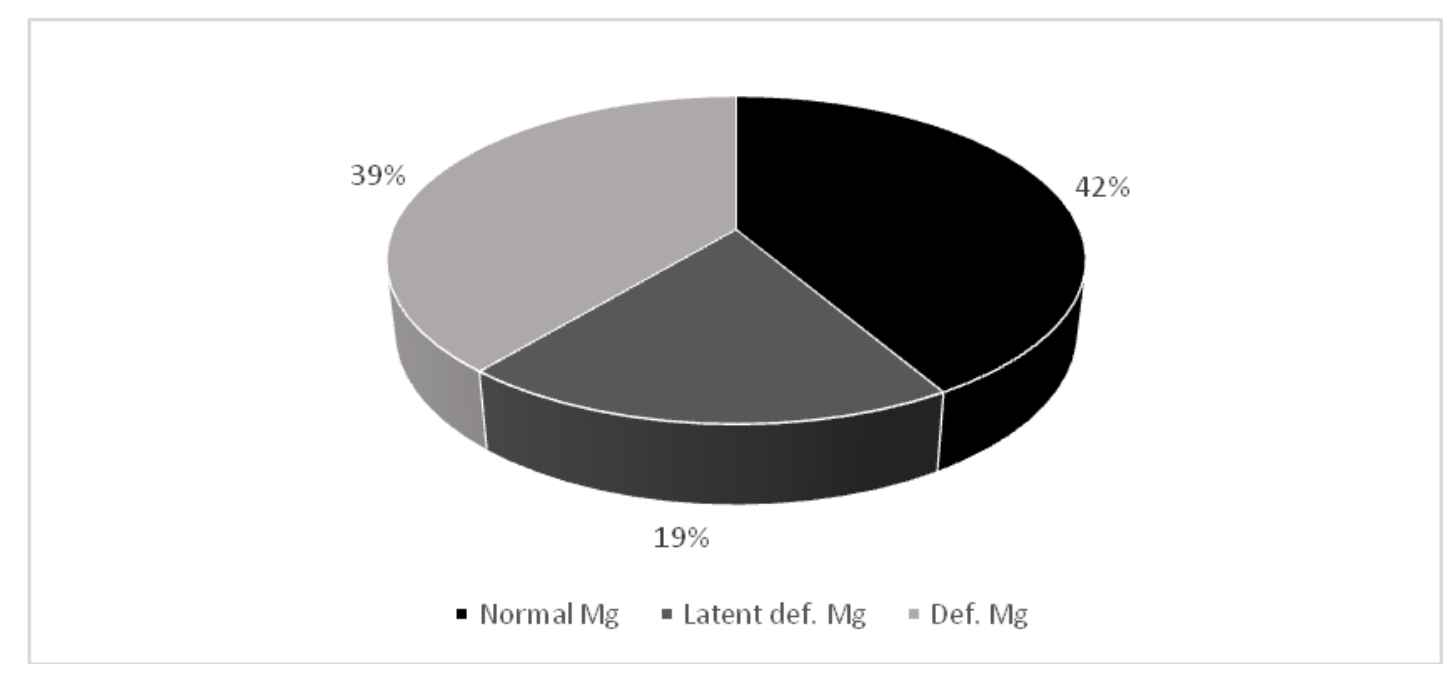

Fig. 2 - The ratio of the number of children in the main group with normal levels, latent deficiency and magnesium deficiency in the analysis of the ratio of $\mathrm{Ca} / \mathrm{Mg}_{\text {erythrocyte. }}$.

Thus, based on the obtained and literature data on the accuracy of the use of the ratio $\mathrm{Ca} / \mathrm{Mg}_{\text {erythrocyte }}$ to assess the latent and evident magnesium deficiency, we used this indicator in the study.

To predict the development of magnesium deficiency in children with GERD, the odds ratio and trusted intervals for many factors were calculated (Table 2). Sex, age of the patient, the main symptoms of gastroesophageal reflux disease and their numerosity, results of instrumental research methods (EGD, pH-metry test, ECG) were considered in the study. 
Table 2. The ratio of the chances of developing magnesium deficiency in children of the main group

\begin{tabular}{|c|c|c|c|c|c|c|c|}
\hline & \multicolumn{4}{|c|}{ Children with GERD $(\mathrm{n}=77)$} & Odds & \multirow[t]{3}{*}{ TI- } & \multirow[t]{3}{*}{ TI+ } \\
\hline & \multicolumn{2}{|c|}{$\begin{array}{c}\text { Normal Mg level } \\
\left(\mathrm{Ca} / \mathrm{Mg}_{\text {erythrocyte }} 1.0\right. \\
-1.36) \\
\mathrm{n}=32 \\
\end{array}$} & \multicolumn{2}{|c|}{$\begin{array}{c}\text { Latent and evident } \\
\text { magnesium } \mathrm{Mg} \\
\text { deficiency } \\
\left(\mathrm{Ca} / \mathrm{Mg}_{\text {erythrocyte. }}>1.36\right) \\
\mathrm{n}=45 \\
\end{array}$} & ratio & & \\
\hline & Yes & No & Yes & No & & & \\
\hline 1 & 2 & 3 & 4 & 5 & 6 & 7 & 8 \\
\hline \multicolumn{8}{|l|}{ Sex: } \\
\hline Girls & 12 & 20 & 20 & 25 & 1.33 & 0.53 & 3.37 \\
\hline Boys & 20 & 12 & 25 & 20 & 0.75 & 0.3 & 1.89 \\
\hline \multicolumn{8}{|l|}{ Age: } \\
\hline 9-14 years old & 14 & 18 & 14 & 31 & 0.58 & 0.23 & 1.49 \\
\hline 15-17 years old & 18 & 14 & 31 & 14 & 1.72 & 0.67 & 4.41 \\
\hline \multicolumn{8}{|l|}{ Symptoms: } \\
\hline Heartburn & 25 & 7 & 39 & 6 & 1.82 & 0.55 & 6.05 \\
\hline Nausea & 14 & 18 & 25 & 20 & 1.61 & 0.64 & 4.0 \\
\hline Eructation & 15 & 17 & 17 & 28 & 0.69 & 0.27 & 1.73 \\
\hline Lump in the throat & 5 & 27 & 4 & 41 & 0.53 & 0.13 & 2.14 \\
\hline $\begin{array}{l}\text { Heaviness in the } \\
\text { abdomen }\end{array}$ & 4 & 28 & 12 & 33 & 2.55 & 0.74 & 8.78 \\
\hline Stomach ache & 5 & 27 & 15 & 30 & 2.7 & 0.87 & 8.42 \\
\hline $\begin{array}{l}\text { Astheno-neurotic } \\
\text { symptoms }\end{array}$ & 20 & 12 & 19 & 26 & 0.44 & 0.17 & 1.11 \\
\hline \multicolumn{8}{|l|}{$\begin{array}{l}\text { Number of } \\
\text { complaints: }\end{array}$} \\
\hline 1-2 complaints & 14 & 18 & 19 & 26 & 0.94 & 0.38 & 2.35 \\
\hline 3-4 complaints & 17 & 15 & 22 & 23 & 0.84 & 0.34 & 2.09 \\
\hline 5-7 complaints & 1 & 31 & 4 & 41 & 3.02 & 0.32 & 28.42 \\
\hline \multicolumn{8}{|l|}{ Acidity: } \\
\hline Normoacidity & 22 & 10 & 19 & 26 & 0.33 & 0.13 & 0.86 \\
\hline Hyperacidity & 6 & 26 & 20 & 25 & 3.47 & 1.2 & 10.05 \\
\hline Hypoacidity & 4 & 28 & 6 & 39 & 1.08 & 0.28 & 4.18 \\
\hline \multicolumn{8}{|l|}{$\begin{array}{c}\text { Esophageal } \\
\text { damage: }\end{array}$} \\
\hline $\begin{array}{l}1 \text { grade of reflux } \\
\text { esophagitis }\end{array}$ & 31 & 1 & 14 & 31 & 0.01 & 0.001 & 0.12 \\
\hline $\begin{array}{l}\text { 2-3 grade of reflux } \\
\text { esophagitis }\end{array}$ & 1 & 31 & 31 & 14 & 68.64 & 8.5 & 554.41 \\
\hline Catarrhal gastritis & 31 & 1 & 39 & 6 & 0.21 & 0.02 & 1.83 \\
\hline Erosive gastritis & 1 & 31 & 5 & 40 & 3.88 & 0.43 & 34.89 \\
\hline $\begin{array}{l}\text { Duodenogastric } \\
\text { reflux }\end{array}$ & 6 & 26 & 13 & 32 & 1.76 & 0.59 & 5.27 \\
\hline H.pylory & 12 & 20 & 18 & 27 & 1.11 & 0.44 & 2.82 \\
\hline
\end{tabular}




\begin{tabular}{|c|c|c|c|c|c|c|c|}
\hline $\mathbf{1}$ & 2 & 3 & 4 & 5 & 6 & 7 & 8 \\
\hline \multicolumn{8}{|l|}{ Duration of illness: } \\
\hline $\begin{array}{l}\text { The disease was } \\
\text { detected for the first } \\
\text { time }\end{array}$ & 5 & 27 & 6 & 39 & 0.83 & 0.23 & 3.0 \\
\hline Duration $1-3$ years & 17 & 15 & 32 & 13 & 2.17 & 0.84 & 5.6 \\
\hline 3 and more years & 10 & 22 & 7 & 38 & 0.41 & 0.13 & 1.22 \\
\hline \multicolumn{8}{|l|}{$\begin{array}{l}\text { BMI (body mass } \\
\text { index): }\end{array}$} \\
\hline P $25-75$ & 14 & 18 & 19 & 26 & 0.94 & 0.38 & 2.35 \\
\hline Less than P 25 & 4 & 28 & 8 & 37 & 1.51 & 0.41 & 5.54 \\
\hline More than P 75 & 14 & 18 & 18 & 27 & 0.86 & 0.34 & 2.15 \\
\hline \multicolumn{8}{|l|}{ QTc interval } \\
\hline Up to $420 \mathrm{mc}$ & 28 & 4 & 35 & 10 & 0.5 & 0.14 & 1.77 \\
\hline More than $420 \mathrm{mc}$ & 4 & 28 & 10 & 35 & 2.0 & 0.57 & 7.06 \\
\hline
\end{tabular}

Among the many factors listed, the following were selected for further analysis: hyperacidity ( $\mathrm{pH} 0.86$ - 1.59), which had odds ratio of 3.47 and reflux esophagitis of 2-3 grades with an odds ratio of 68.64. Patients with erosive gastritis were not considered (although this symptom had odds ratio of 3.88). Patients with erosive gastritis were considered in the group of children with hyperacidity.

The calculation of the odds ratio of developing magnesium deficiency was also performed for main temporal and spectral indicators of HRV analysis (Table 3). For further analysis, HRV indicators were used, which had odds ratio higher than 3.0. These indicators were: increase in LF and HF during the day and night, increase in the daily LF/HF ratio, increase in the stress index, increase in PAPR and average circadian index.

Table 3 - The ratio of the odds of indicators of HRV in the development of magnesium deficiency in children of the main group

\begin{tabular}{|c|c|c|c|c|c|c|c|}
\hline & \multicolumn{4}{|c|}{ Children with GERD $(\mathrm{n}=77)$} & \multirow[t]{3}{*}{ Odds ratio } & \multirow[t]{3}{*}{ TI- } & \multirow[t]{3}{*}{ TI+ } \\
\hline & \multicolumn{2}{|c|}{$\begin{array}{c}\text { Normal } \mathrm{Mg} \text { level } \\
\left(\mathrm{Ca} / \mathrm{Mg}_{\text {erythrocyte }} 1.0\right. \\
-1.36) \\
\mathrm{n}=32\end{array}$} & \multicolumn{2}{|c|}{$\begin{array}{c}\text { Latent and evident } \\
\text { magnesium } \mathrm{Mg} \\
\text { deficiency } \\
\left(\mathrm{Ca} / \mathrm{Mg}_{\text {erythrocyte. }}>\right. \\
1.36) \\
\mathrm{n}=45 \\
\end{array}$} & & & \\
\hline & Yes & No & Yes & No & & & \\
\hline 1 & 2 & 3 & 4 & 5 & 6 & 7 & 8 \\
\hline \multicolumn{8}{|l|}{ LF day } \\
\hline LF day $<64.15$ & 19 & 13 & 12 & 33 & 0.25 & 0.09 & 0.65 \\
\hline LF day 64.16-67.33 & 4 & 28 & 8 & 37 & 1.51 & 0.41 & 5.54 \\
\hline LF day $>67.34$ & 9 & 23 & 25 & 20 & 3.19 & 1.21 & 8.42 \\
\hline
\end{tabular}




\begin{tabular}{|c|c|c|c|c|c|c|c|}
\hline $\mathbf{1}$ & 2 & 3 & 4 & 5 & 6 & 7 & 8 \\
\hline \multicolumn{8}{|l|}{ LF night } \\
\hline LF night $<40.35$ & 5 & 27 & 1 & 44 & 0.12 & 0.01 & 1.11 \\
\hline LF night 40.36-45.91 & 7 & 25 & 1 & 44 & 0.08 & 0.01 & 0.07 \\
\hline LF night $>45.92$ & 20 & 12 & 43 & 2 & 12.9 & 2.64 & 63.14 \\
\hline \multicolumn{8}{|l|}{ HF day } \\
\hline HF day $<27.16$ & 5 & 27 & 18 & 27 & 3.6 & 1.17 & 11.09 \\
\hline HF day 27.17-41.36 & 19 & 3 & 23 & 22 & 0.17 & 0.04 & 0.64 \\
\hline HF day $>41.37$ & 8 & 24 & 4 & 41 & 0.29 & 0.08 & 1.08 \\
\hline \multicolumn{8}{|l|}{ HF night } \\
\hline HF night $<50.9$ & 21 & 11 & 40 & 5 & 4.19 & 1.29 & 13.66 \\
\hline HF night 51.0-56.84 & 4 & 28 & 2 & 43 & 0.33 & 0.06 & 1.9 \\
\hline HF night $>56.85$ & 7 & 25 & 3 & 42 & 0.26 & 0.06 & 1.08 \\
\hline \multicolumn{8}{|l|}{ LF/HF day } \\
\hline $\mathrm{LF} / \mathrm{HF}$ day $<1.89$ & 18 & 14 & 6 & 39 & 0.12 & 0.04 & 0.36 \\
\hline LF/HF day 1.9-2.21 & 9 & 23 & 11 & 34 & 0.83 & 0.3 & 2.31 \\
\hline LF/HF day > 2.22 & 5 & 27 & 28 & 17 & 8.89 & 2.88 & 27.5 \\
\hline \multicolumn{8}{|l|}{ LF/HF night } \\
\hline LF/HF night $<0.8$ & 7 & 25 & 1 & 44 & 0.08 & 0.01 & 0.7 \\
\hline LF/HF night 0.81-0.9 & 6 & 26 & 1 & 44 & 0.1 & 0.01 & 0.86 \\
\hline LF/HF night $>0.91$ & 19 & 3 & 43 & 2 & 3.39 & 0.52 & 22.0 \\
\hline \multicolumn{8}{|l|}{ SI day } \\
\hline SI day $<32.9$ & 16 & 6 & 5 & 40 & 0.05 & 0.01 & 0.18 \\
\hline SI day 33-40.3 & 9 & 23 & 6 & 39 & 0.39 & 0.12 & 1.25 \\
\hline SI day $>40.4$ & 7 & 25 & 34 & 11 & 11.04 & 3.75 & 32.48 \\
\hline \multicolumn{8}{|l|}{ SI night } \\
\hline SI night $<14.8$ & 2 & 30 & 4 & 41 & 1.46 & 0.25 & 8.52 \\
\hline SI night 14.9-16.6 & 2 & 30 & 4 & 41 & 1.46 & 0.25 & 8.52 \\
\hline SI night $>16.7$ & 28 & 4 & 37 & 8 & 0.66 & 0.18 & 2.42 \\
\hline \multicolumn{8}{|l|}{ PAPR day } \\
\hline PAPR day <33 & 13 & 19 & 6 & 39 & 0.22 & 0.07 & 0.68 \\
\hline PAPR day 33.1-36.7 & 13 & 19 & 8 & 37 & 0.32 & 0.11 & 0.89 \\
\hline PAPR day $>36.8$ & 6 & 26 & 31 & 14 & 9.6 & 3.23 & 28.52 \\
\hline \multicolumn{8}{|l|}{ PAPR night } \\
\hline PAPR night $<21.5$ & 3 & 29 & 6 & 39 & 1.49 & 0.34 & 6.45 \\
\hline PAPR night 21.6-24.1 & 1 & 31 & 6 & 39 & 4.77 & 0.55 & 41.73 \\
\hline PAPR night $>24.2$ & 28 & 4 & 33 & 12 & 0.39 & 0.11 & 1.36 \\
\hline \multicolumn{8}{|l|}{ CI } \\
\hline Less than 1.2 conv. unit & 10 & 22 & 7 & 38 & 0.41 & 0.13 & 1.22 \\
\hline 1.2-1.4 conv. unit & 17 & 15 & 35 & 10 & 3.09 & 1.15 & 8.29 \\
\hline $\begin{array}{l}\text { More than } 1.4 \text { conv. } \\
\text { unit }\end{array}$ & 5 & 27 & 3 & 42 & 0.39 & 0.09 & 1.75 \\
\hline
\end{tabular}

After determining the GERD factors that had the highest odds ratio for predicting the development of magnesium deficiency, the relative risk indicators and the minimum and maximum prognostic coefficients for these factors were determined (Table 4). 
Table 4 - Selected factors for the prediction of magnesium deficiency during GERD

\begin{tabular}{|l|c|c|c|}
\hline \multicolumn{1}{|c|}{ Factor } & OR & Xmin & Xmax \\
\hline Hyperacidity grade of reflux & 3.47 & 1.3 & 3.12 \\
\hline \begin{tabular}{l} 
2-3 $\begin{array}{c}\text { graghatis } \\
\text { esoph.64 }\end{array}$ \\
\hline LF day $>67.34$
\end{tabular} & 3.19 & 1.7 & 36.5 \\
\hline LF night $>45.92$ & 12.90 & 1.3 & 2.5 \\
\hline HF day $<27.16$ & 3.60 & 1.3 & 1.8 \\
\hline HF night $<50.9$ & 4.19 & 1.1 & 1.5 \\
\hline LF/HF day > 2.22 & 8.89 & 1.5 & 5.8 \\
\hline SI day $>40.4$ & 11.04 & 1.4 & 4.9 \\
\hline PAPR day >36.8 & 9.60 & 1.4 & 5.3 \\
\hline CI 1.2-1.39 & 3.09 & 1.2 & 1.7 \\
\hline
\end{tabular}

Based on the indicators of the minimum and maximum prognostic coefficient, the range of probability of magnesium deficiency in patients with GERD from 13.3 to 66.5 was formed. This range was divided into the three parts (Table 5).

Table 5 - Ranges of probability of magnesium deficiency in GERD

\begin{tabular}{|l|c|}
\hline \multicolumn{1}{|c|}{ Probability } & Points \\
\hline Mild & $13.3-31.0$ \\
\hline Medium & $31.1-48.8$ \\
\hline High & $48.9-66.5$ \\
\hline
\end{tabular}

With the sum of the prognostic coefficients of each significant factor from 13.3 to 31.0 , the probability of magnesium deficiency is weak; the range from 31.1 to 48.8 is the average probability, and the range from 48.9 to 66.5 indicates a significant probability that a patient with GERD has magnesium deficiency.

Conclusions. Among the children with GERD who participated in the study in almost half of the cases magnesium deficiency with varying grades was found. It is noteworthy that the analysis of erythrocyte magnesium showed a latent deficiency in $22 \%$, and a significant magnesium deficiency in $27 \%$ children with GERD, while using the ratio $\mathrm{Ca} / \mathrm{Mg}_{\text {erythrocyte, the }}$ latent deficiency in 19\% and a significant deficiency in 39\%. The obtained data testified to the greater accuracy of using the $\mathrm{Ca} / \mathrm{Mg}_{\text {erythrocyte }}$ ratio to assess latent and evident magnesium deficiency.

There was also a significant prevalence of magnesium deficiency in children with GERD. Factors of the course of GERD that can be used as prognostic factors for magnesium deficiency have been identified. Such factors include hyperacidity ( $\mathrm{pH} 0.86-1.59$ ), the reflux 
esophagitis 2-3 grades, increase in daytime and night time LF and HF, increase in the daily ratio of $\mathrm{LF} / \mathrm{HF}$, increase in stress index, increase PAPR and circadian index averages.

The indicators of the minimum and maximum prognostic coefficient for these factors were calculated and the range of probability of magnesium deficiency in patients with GERD was formed, which was divided into mild, medium and high probability of magnesium deficiency.

Financing. The study has been performed in the framework of the planned research scientific work of the Children's Diseases Department of ZSMU titled "The peculiarities of the development of diseases and the elaboration of the programs of rational nutrition, of therapeutic and rehabilitation measures improvement, and of prevention of distresses in children of different age, who reside in an industrial city” state registration № 114U001397.

\section{Conflict of interests: none.}

\section{References}

1. Marushko $\mathrm{Yu} . \mathrm{V}$ and co-authors. Correction of lack of magnesium in children and adolescents with asthenic syndrome and primary arterial hypertension. Rational pharmacotherapy №3. 2016; (40):35-48.

2. Beketova G, Gnatenko T. Magnesium and health of children: what is the news? Shupyk National Medical Academy of Post-Graduate Education, Kyiv, Ukraine. 2016;4(4):604-620.

3. Boiarskaia L.N., Potapenko S.V. Optimization of pathogenetic therapy of gastrooesophageal reflux disease in children. Modern pediatrics. 2017;4(84):86-90; doi 10.15574/SP.2017.84.86.

4. Kryuchko T.O. Features of extraesophageal manifestations of gastroesophageal reflux disease in children. Child health. 2013; 4(47): 16-19.

5. DiNicolantonio J.J., O'Keefe J.H., Wilson W. Subclinical magnesium deficiency: a principal driver of cardiovascular disease and a public health crisis. Open Heart. 2018;5:e000668. doi: 10.1136/openhrt-2017-000668. 